\title{
Dorota Michułka
}

University of Wrocław, Poland

dorota.michulka@uwr.edu.pl

\section{Crossing the Boundaries of Imagination Romantic experience of existence, nature, and the mystery of characters in Emilia Kiereś's parabolic fairy tales Brat and Lowy}

Izvorni znanstveni rad / original research paper

Primljeno / received 12. 10. 2016. Prihvaćeno / accepted 10. 3. 2017.

DOI: $10.21066 /$ carcl.libri.2017-06(01).0002

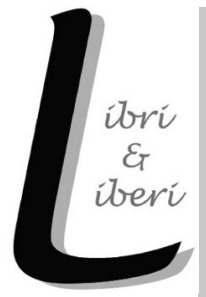

The ethical context in which the stories Brat and Lowy by Emilia Kiereś are clearly rooted - especially considering the literary expectations of a young reader - allows the phenomenon of imagination also to be observed and discussed in terms of humanistic values, which are a very important aspect of Polish studies. In Kiereśs works, the power of imagination of the protagonists and the crossing of its boundaries are a sort of ethical imperative that motivates the heroes into action. In both stories by Emilia Kiereś, which are deeply rooted in the poetic of the fairy tale, fantasy and folk tale, the Romantic experience of existence, the mystery of nature, and the characters themselves appear in the context of ethical values. Therefore, in addition to the convention of the Romantic fairy tale, both stories also take the genealogical form of a parable.

Keywords: imagination, ethical values, Romantic fairy tale, parable, folklore, nature, mystery

\section{Romantic experience of existence}

Brat [Brother] (2011) and Łowy [Hunting] (2012) by Emilia Kiereś are literary fairy tales and parables inspired by folk tales clearly rooted in the Romantic tradition (cf. Natov 2003). The structure of the world depicted on their pages draws on themes in ballads by Adam Mickiewicz (e.g. the story Łowy refers directly to the ballad Świtezianka, whose text is even included at the end of the book) and Slavic mythology (e.g. the fantastic creatures in the stories, such as bożęta, are of Slavic origin; some characters also have Slavic names, e.g. Derwan, Nawojka, and Dobiechna). ${ }^{1}$

1 See W. Danek's (1975) introduction to J.I. Kraszewski's Stara baśń, reviewed and supplemented by S. Burkot. See also Mity, podania i wierzenia dawnych Stowian by J. Strzelczyk (1998), two books by C. Lévi-Strauss, Myśl nieoswojona (1969) and Antropologia strukturalna (1970), as well as Dawni Stowianie - wiara i kult by S. Urbańczyk (1991: 126). For example, Derwan was a prince of the tribe of Lusatian Sorbs, mentioned in the Fredegar chronicle in ca. 632 (cf. Labuda 2009: 104-105). 
In Kiereś's work, the protagonists' power of imagination and the crossing of its boundaries are a sort of ethical imperative that motivates the heroes into action thanks to the skilful merging of the elements of the fantasy world with the real world, which allows the characters to move freely from one world to the other. ${ }^{2}$ The driving force behind the struggles of the heroes of Kiereśs stories is, therefore, both a fairy-tale fantasy (e.g. in the story Brat, a walk through the enchanted forest is a search for independence, a kind of "rite of passage" thanks to which the protagonists become able to make their own decisions, renew their love, try to find their own identity, and learn more about themselves) and folk fantasy, supernatural powers, an irrational and transcendental world, as well as wonder and mysticism. One of the aspects of the books that significantly inspires imagination is the uncertainty of the protagonists and the mystery itself of the folk stories, whose solution is suggested by ambiguous interpretations of secret signs, hunches, intuitions, and allusions that motivate the characters into action (e.g. the cause of the banishment of the brothers' father; the mysterious disappearance of Jan; the huge bird of prey attacking the wayfarers; the beautiful nymph having a "suspiciously friendly" chat with one of the protagonists; the sounds of a storm and the ominous wind over the lake in Płużyny; an enchanted, underwater city that rises to the surface of the lake at the end of a silver thread held by the little Marylka, etc.). ${ }^{3}$

Such an extensive and bold combination of fantasy and realism, which is the dominant artistic feature of Kiereśs stories, may have its roots in the poetic structure of Romantic fairy tales, especially those from the German literary circle. Waksmund observes that the German Romantics (2000: 195): ${ }^{4}$

$[\ldots]$ were not attracted to $[\ldots]$ the royal splendour of fairy-tale kingdoms with their intrigues and love affairs, but to the world of common subjects concerned about their daily bread, who are amazed to learn that some things are beyond common sense and outside their system of values. A combination of [the] ideal and reality [after all] gives birth to Hoffmann's "double reality" manifesting itself in a specific manipulation of events, characters, time, and space, which brings such plots close to the world of children's play, with its countless masks and scenarios. ${ }^{5}$

The name Nawojka comes from the male form Nawoj, which is an Old Polish name; etymologically, Nawoj consists of two parts: $n a$ (best) and woj (warrior); the meaning of this name is associated with the desire to be a good (the best) warrior; the name was borne, for instance, by a knight from Nowy Sącz. On the other hand, the term bożęta (sing. uboże, ubożę, pl. freq. uboża, ubożęta) etymologically comes from the root bog-, i.e. grace, wealth; it means protective house spirits, creatures derived from Old Polish beliefs, also associated with the souls of dead ancestors; one $15^{\text {th }}$-century sermon includes information on leaving meal leftovers to such godlings (cf. Szyjewski 2003: 186).

2 See Niemiecka baśń romantyczna by G. Koziełek (1967), Żywioły wyobraźni poetyckiej XIX $i$ $X X$ wieku, edited by A. Czabanowska-Wróbel, A. Misiak and I. Misiak (2008), as well as two publications by A. Czabanowska-Wróbel, Baśń w literaturze Młodej Polski (1996) and Dziecko. Symbol i zagadnienie antropologiczne w literaturze Młodej Polski (2003).

3 See works by Cz. Zgorzelski $(1948,1962,1978)$ and Romantyzm by A. Witkowska and R. Przybylski (2009).

4 All translations of quotations into English are by D.M.

5 In her interpretation of The Mysterious Child by E.T.A. Hoffmann and comments on the "double reality" of the represented world, E. Pieciul-Karmińska observes (2014: 8-9): 
The family of the brothers Mir and Wir (from the tale Brat) seems to be an "ordinary", lower-class family, with the bright and clear image of the mother taking care of the household, the father who is a hunter and woodcutter working in the forest, and the nanny who helps with the chores. In addition, a natural part of this reality includes household goblins - bożęta - concerned with housekeeping, keeping things in order, and taking care of the health of the family, who help with the daily work and dedicatedly wander the world in search of the missing Wir.

As Waksmund notes (2000: 193):

Adventurous and heroic themes were subordinated [here] to psychological ones, which, in turn, expressed the condition of a man torn between nature and transcendence, and the banality of everyday life. Such an ambitiously formulated idea of the genre would never have affected the development of fairy tales for children if not for the fact that, in the opinion of Romantics, a child as a human being was a relatively fresh creature of nature uncontaminated by civilisation, thus capable of feeling and understanding the transcendental world, which was best expressed by poetry and myth. ${ }^{6}$

So, the child heroes of the story Łowy can see and feel more than adults, and naturally/spontaneously decide to unravel the secret of the mysterious lake and the nymph temptress with whom young men fall in love (including the elder brother of one of the boys) but whom no one has ever seen.

Although the heroes show immense emotional involvement in the course of events, and the child's imagination works impeccably, the children would also like to act with prudence and caution. They are surprised to learn that the men could not describe the girl they had fallen in love with; as a result, they assume the roles of small detectives and, using logical deduction, begin to analyse the situation. Their discussion would not be out of place in a school lesson on the subject of "folk beliefs" (Kiereś 2012: 62-63):

"Maybe it's because they met her in the evenings, when it was dark", Maryla said thoughtfully.

Michał became slightly disconcerted, “Maybe, but I don't think so. On a summer night, especially in moonlight, you can still see s o meth in $\mathrm{g}$ - even quite a bit. I think there is another reason".

[...] the description of the events [in this story], where the parents eyewitness the transformation of the teacher into a monstrous fly and the father confesses that during his childhood he met a fairy-tale creature, gives specific evidence of the reality of the fantasy world. This way we find inside the fairy tale two really existing worlds and we know from the start which side is favoured by the narrator. The world of rational people is for him not only boring, pretentious, and limited (which we learn through a bravura description of a visit by relatives), but also reveals its destructive power when Master Inkaust turns out to be an evil gnome. This point of view could not be presented any more clearly. At the same time, the author uses stylistic devices thanks to which the nature surrounding the children seems to be magical and alive. Interestingly, the description of the wonderful land of fairies uses as many lofty epithets, personifications, and comparisons as the description of a real forest in which children play every day. [...] It is easy to notice here a clearly marked dichotomy between childhood and adulthood as well as the symbolism of the story, in which the mysterious child is proof that the key to happiness in this life is the power of imagination and harmony with nature [emphasis added].

6 See also E. Pieciul-Karmińska, “'Tajemnicze dziecko' - zapomniany skarb literatury światowej A Word from the Translator", in: E.T.A. Hoffmann, Tajemnicze dziecko, illustrated by A. KucharskaCybuch, Media Rodzina, 2014. 
"And what is that?"

"Can you think of something whose appearance you cannot describe?"

Maryla and Franek looked at each other bewildered. "I think... basically anything can be described one way or another", concluded Franek after a moment's silence.

"I know! You can't describe something that isn't there!" cried Maryla in triumph.

Franek felt shivers down his spine. "But he must have seen her", he said uncertainly, "and since he saw her, she was there".

"He claimed he had seen her", replied Maryla emphatically, "and that's not the same thing".

The boy shifted nervously. "But they couldn't have both imagined her", he protested feebly.

"Of course not", agreed Michał.

"You can't see things that aren't there, that's true. But you also can't see things that are intangible... Do you understand?" she asked, flicking her gaze between her sister and her friend.

"For example, you can't see air but it's still there", observed Franek.

"This girl was not human!" shouted Maryla, "I told you so from the beginning".

"And who was she, then? A ghost?" asked Franek impatiently.

"No, not a ghost. Rather a water nymph... you know, a świtezianka. People say that there are maids - świtezianki - living in our lake".

"Exactly", Michał nodded, "neither of them could say anything about her because she was immaterial... They could see her, but she was completely indeterminate. As if she had no appearance".

Let us move at this point to reliable literature. Wielka księga demonów polskich [The Great Book of Polish Demons] includes the following definition of the term rusalka (Podgórscy \& Podgórska 2005: 389):

The name comes from the Latin phrase dies rosae - the name of a Slavic rite of spring, known in pagan Eastern Europe as rosalia. They belong to the category of negative female demons who personify forces of nature, are hostile to people, cause them trouble or even kill them. Folk beliefs distinguished two main groups of such demons: water rusalki and land rusalki dwelling outside water reservoirs; the latter were in turn subdivided into rusalki of the forest and rusalki of the meadows. According to folk beliefs, rusalki spent the winter in the water, and in the spring they appeared in forests and groves. They were believed to be the souls of prematurely deceased girls.

Underwater rusalki - the kind present in the story by Kiereś - had the figure of a young, beautiful girl, who performed lively dances, often in the moonlight; they were completely naked or covered with a thin, transparent, long robe and had loose green or golden hair, sometimes decorated with a garland of seaweed. Dictionaries of demonology, whose explanations include the context of folk culture, add here the following information, emphasising the power of nature and elements of erotic images (Podgórscy \& Podgórska 2005: 391):

$[\mathrm{R}]$ usalki $[. .$.$] arise from the souls of children who died during baptism or innocent$ girls who died in sudden and unusual circumstances; they live in water depths and are the guardians of water, punishing by death (drowning) anyone who violates or defiles their waters [...]. In places touched by their feet, the grass is always moist, lush, and green. They like to sit and swing on the branches of willows growing over 
the water. They can spend hours combing their beautiful hair and they tempt passersby, especially handsome young men, trying to lure them with dancing and amorous frolics. When they succeed, they tickle them breathless, senseless, ultimately causing their death, or the victims are drawn by them to the greatest depths, never to return. People drowned by rusalki increase the numbers of water demons. ${ }^{7}$

In his discussion of the origin of the "water maid" presented against the background of a broader study of folklore, Michał Fijałkowski in the article "Rusałki słowiańskie ondyny" [Rusalki - Slavic Undines] (2014) writes that, in accordance with folk Romantic beliefs, a rusalka/nymph/mermaid took the form of an often evil and ugly woman, a cruel and malicious spirit of nature, while in literature she appears as a beautiful, passionate seductress with black or golden hair and black eyes. ${ }^{8}$ Fijałkowski further states that (23):

In a footnote to Świtezianka (1821), Adam Mickiewicz provides the following information: "Rumour has it that on the banks of Lake Świteź one can notice ondines, i.e. water nymphs, which the commoners call świtezianki" (Mickiewicz 499). It is obvious that Mickiewicz (if only on the comparative level) refers to the famous folk story Undine by Friedrich de la Motte Fouqué (1811), which describes an impossible love between a knight named Huldebrand and Undine, the daughter of the ruler of the water kingdom. As is demonstrated by Kraß in his work, Undine was not the first modern literary elaboration of the theme that Paracelsus described in his work Liber de nymphis, sylphis, pygmaeis et salamandris, et de caeteris spiritibus. Already in 1795, Christian August Vulpius published Die Saal-Nixe, the first German novel about a water nymph, which was widely received. This was the basis for the famous play Das Donauweibchen by Karl Friedrich Hensler (1798), known, among others, to Hans Christian Andersen, whose fairy tale The Little Mermaid (Den Lille Havfrue, 1836) is at present the most popular and key realization of the theme started by Vulpius. ${ }^{9}$

The horror of the scene of the temptation of Wir by the nymph is also emphasised in the story Brat by the predatory eagle owl - a symbol of fortune, fate, and destiny which closely watches the meeting of the hero with the underwater temptress (Kiereś 2011: 78):

7 See also Zwyczaje, obrzędy i tradycje w Polsce by B. Ogrodowska (2001).

8 See also "Piękna Meluzyna. Cudowna historia o morskiej pannie i jej walecznym potomstwie" in the anthology edited by Tadeusz Żabski \& Jolanta Lugowska (Anon 1992: 41-75). See also books by Aleksander Brückner, Mitologia słowiańska (1918) and Mitologia polska (1924).

9 References to Undine by de la Motte Fouqué can later be found in Swan Lake by Tchaikovsky, Rusalka by Dvořák and Pelléas and Mélisande by Maeterlinck, for which Debussy composed an opera. M. Fijałkowski (2014: 25) writes:

The character of a rusalka, who with her supposedly Slavic origin is the counterpart of a nymph known from Western European literatures, appears in Slavic literatures at the beginning of the $19^{\text {th }}$ century during the period of the formation of Romanticism, heavily imbued with folklore elements. However, the wealth of diverse, often conflicting literary representations of this character creates a huge problem of how to precisely define Slavic rusalki. Bronisław Trentowski in "Wiara słowiańska" [see note $\boldsymbol{a}$ below] calls them bogunki, water nymphs, "who accompanied the goddess Leluja. The home river of the bogunki was the Bug and from there they moved to the Narew, the Vistula, the San, the Pilica and other Polish rivers and streams. On the other hand, the river of the rusalki was the holy Rus" [see note $\boldsymbol{b}$ below]. 
Its soft, tawny brown feathers fluttered in the wind and the long, black, curved claws were grasping the branch. The bird was looking straight at Wir and the serious, stern stare of its golden irises paralysed the boy, rendering him motionless. Unable to take his eyes off the bird, Wir heard a voice, but could not tell whether it was coming from the outside or speaking in his head: "You can't change your destiny". There was shrill, wild laughter, rolling like thunder. The horse whinnied, reared up, and galloped forward, disappearing into the darkness between the trees. The owl spread its huge, striped wings and glided down onto Wir, knocking him to the ground.

In the end, Wir is pulled underwater by a rusalka - the water surface closes over him, forming a hard, enchanted, but transparent shell. The rusalka's power does not reach here; instead, the vodyanoy reigns supreme (Kiereś 2011: 99-100):

He was a man with greenish skin covered with small scales. His head was covered with hair resembling bulrush, out of which protruded two thick, curled-back horns. The sunken eyes stared gloomily at Wir; it seemed to the boy that he saw inside them only an empty, immeasurable abyss. Only when he looked into those eyes did he feel as if he was drowning [...]. "Rusalki [...] are frivolous and noisy creatures", the vodyanoy winced, "and they enjoy teasing. Sometimes, very rarely, they may take a liking to someone", he added in an explanatory tone. "Perhaps she preferred to leave you so that she wouldn't hurt you later on. You can't hold back your true nature for long”.

The underwater world makes the hero depressed. The imagination of Wir and the unique "inner space" created by him additionally evoke memories of an earthly nature and the family house in the forest. The conflict with his brother, the anguish after his loss, the feeling of guilt and moral self-examination, and the drama of the situation with no way out as in an ancient tragedy are further confirmed by the words of the vodyanoy (Kiereś 2011: 102):

In his work, Kraß classifies the nymph characters not only by names (mermaid, Melusine, Donauweibchen, Loreley, undine) and the roles played by such characters in the stories but also by their external appearance (woman-bird, woman-snake, woman-fish). While the Polish word for mermaid (syrena) has various meanings, this is not a problem for the German-speaking author because of the richness of available terms: the woman-bird known from The Odyssey is Sirene; by contrast, the mermaid with a fish's tail, known from a fairy tale by H.C. Andersen, is Meerjungfrau or Seejungfrau.

In the example of Polish ballads whose heroine is a mermaid, we can clearly see the difference between the concepts of authentic village folklore and the artificial, although strongly traditionalised, literary folklore ... Like the Romantics of the Borderland, the Great Polish poet Ryszard Berwiński "cast" his rusalka into the waters of Lake Gopło by creating his Bogunka na Gople (1840), which shares many similarities with the character Goplana in Balladyna (1839) by Juliusz Słowacki.

$\boldsymbol{a}$ "Wiara słowiańska" is part of the extensive work Bożyca lub teozofia, which Trentowski worked on from 1842 but never published (it exists in manuscript form); however, the above-mentioned fragments on Slavic mythology were included by Tadeusz Linkner in his book Stowiańskie bogi i demony. Z rękopisu Bronisława Trentowskiego (1998).

$\boldsymbol{b}$ The etymology of the name rusalka presented by Trentowski has been contradicted by recent studies, which suggest that the name comes not from Slavic languages but from Latin - dies rosae, rosalia, the ancient Roman festival of roses, in the Greek form: rusalia. In Mitologia Stowian, Aleksander Gieysztor (1986) admits that, with respect to this word, "the (Orthodox church) path and the time of the borrowing remain a mystery". 
You are underwater, but you're not drowning [...] the men who go to the bottom are the ones I drag underwater myself when they cross me. You came to me by chance. That's why you are in between - here, where the reflection is born. Just under the surface. You can choose where to go - whether to join the drowned or return to the surface [...] [but] if someone wants to get out of here, he must give me a hostage in exchange [...] [who] will remain with me forever [...] but this must be someone in whose veins flows the same blood as yours [...] [and you] - have a brother, don't you?

A kind of spiritual "limbo" of the hero may be interpreted here in the context of Michel Foucault's theory of "other spaces", heterotopias, "non-hegemonic worlds", "worlds in-between" (1984: 48), which exist not only physically but also spiritually. As Foucault writes (49):

We do not live in a homogeneous and empty space, but on the contrary in a space thoroughly imbued with quantities and perhaps thoroughly fantasmatic as well. The space of our primary perception, the space of our dreams and that of our passions hold within themselves qualities that seem intrinsic: there is a light, ethereal, transparent space, or again a dark, rough, encumbered space; a space from above, of summits, or on the contrary a space of mud from below; or again a space that can be flowing like sparkling water, or a space that is fixed, congealed, like stone or crystal.

As in many Romantic fairy tales, an important structural element of the stories by Kieres is often their wild and dynamic nature, which stimulates the imagination and in which the characters are "immersed". Nature fulfils different functions in the structure of the story: it provides an all-important setting for the events taking place, reflects the inner states of the human mind, has a magical power that allows it to interfere in the lives of the characters, and "itself gains the status of one of the characters" (Waksmund 2000: 193). Here, in the case of books for a young audience, the impact of nature on the child's imagination is clearly associated with:

1) human existence (e.g. the image of a dead forest, in which there is sinister silence, and of a living forest - although both are parts of the natural cycle/seasons of the year, they evoke different emotions) (cf. Bachelard 1958/1961);

2) the formation of ethical attitudes (e.g. building friendships; highlighting the role of love; taking into account the importance of loyalty, the experience of brotherhood and the essence of fidelity and devotion; distinguishing the dichotomy of good and evil, honesty and dishonesty, diligence and laziness, etc.) (cf. Sainsbury 2013); and

3) folk morality (e.g. the fact that evil is always punished).

The Romantics, who discovered and promoted the so-called "soul of nature", treated it as a mysterious, wonderful, constantly regenerating creature - eternally alive, compared with the infinity of the cosmos, described here as a living organism working efficiently thanks to connections between different elements and man "cast in the main role". The German philosopher Friedrich Wilhelm Joseph von Schelling even introduced the term natura naturans (nature as productivity) (cf. Dehnel 1992). Before Schelling, the concept of nature had already been analysed by J.J. Rousseau, who rejected culture 
in favour of nature, while Friedrich Schiller introduced its different varieties, e.g. "raw nature" - a non-reflective state of happiness and peace; "true nature" - a harmonious realisation within the human world of essential values, achieved in Greek antiquity; he contrasted the above with "real nature" - lacking the direct presence of the ideal; and, finally, future-oriented "new nature" - an artistic realisation of the absolute, a fully individualised ideal free of limitations, a visible presentation of infinity going beyond each finite term (Schiller, 1795). In Poland, Schelling's theories were propagated by Maurycy Mochnacki in his treatise $O$ literaturze polskiej $w$ wieku dziewiętnastym (1830). The researcher interprets nature as a dynamic, spiritual phenomenon, "allprocessual" and "all-spiritual".

Thanks to their vivid narratives visualising the emotional and spiritual states of the heroes, both analysed stories by Kiereś - Brat and Łowy - show the characteristic fusion of a man/child with nature and a full understanding of nature gained by experiencing it. Waksmund provides an example of such a Romantic model (2000: 194):

For example, the pair of siblings from the story The Mysterious Child by E.T.A. Hoffmann have an intimate communication with nature (Das fremde Kind, 1817). Felix and Christine come into conflict with their disgusting private tutor who is in fact the King of Gnomes in disguise persecuting their forest playmate - a child from an unknown land, who exposes them to the wonder and grandeur of nature. The parents side with their children and the father, who is brought to death by the gnome's revenge, admits on his deathbed that he had similar experiences which, however, were obscured by his adulthood years.

It seems that a similar situation will take place in the stories by Kiereś. Both child and adult characters of the stories Brat and Łowy get to know the "soul of nature" in a natural and spontaneous way by living in the bosom of nature - they experience its wonder and extraordinariness, but it also fills them with awe and trepidation, they merge with it and become its part. To quote Bartoszewicz (1991: 593-594):

Nature speaks to man and through man. The challenge for man is to be able to transmit this speech and read in the book of nature. Read anew. Not, as before, by the rational mastery of the immutable laws of nature, but by exploring its secret forces with the power of intuition, intuition of a genius.

However, the heroes' inner power of imagination, stirred by associations with the transcendental world of spirits and miracles known from stories heard in childhood, prevents them from freely moving around the old, dense forest that has not yet been reached by people. A description of the forest region is rooted in the style of Gothic horror. The heroes in Łowy must overcome fear to penetrate the area "between grim spruces with drooping, dark branches" (Kiereś 2012: 121), among alders, on springy ground, breathing heavy, musty, damp air. Kiereś continues (6):

$[\ldots]$ the rotten wood of fallen trees was shining in the dark, in places there were overflowing puddles - some of them dark grey, others covered with a thick mat of duckweed [...] and boggy areas, marshes, where it was safer not to enter, especially after dark $[\ldots]$. There were many places here as yet untrodden by man and many 
places guarded by treacherous swamps and rotten fallen trees. Bountiful wild game populated forest hideouts; some claimed that you may also come across other creatures unlike animals or men.

\section{Mystery and folk}

As has already been emphasised in the interpretative discussions, the folk vision of the world plays an important role in both stories. In the period of Romanticism, people and folklore became overarching concepts in both historic-philosophical and literary reflections and took on a nationwide dimension. It should be recalled here that, in contrast to the Enlightenment, which despised the common folk, Romanticism in a way elevated their status and that of folklore. Fascination with folk spiritual culture was due to its original, native Slavic character. For the Romantics, folk culture was extraordinary because of its spiritual character based on a "secret knowledge" that assumed a special relationship between man and nature, transcendence, and the entire cosmos. In addition, the Romantics were fascinated by folk knowledge of the entire world of nature (e.g. herbs, plants, including flowers and trees, animals, weather phenomena, types of rocks and stones, etc.) and clear ethical principles that were consistently observed.

In Kiereś's stories, the folk vision of the world is also combined with the concept of mystery - hugely important for the young audience's literary reception - used in the story also in the context of the emotional involvement of the reader.

Mystery, initiation, strangeness, riddle, darkness, vagueness, dark visions, quirky imagination - these are keywords describing the Romantic stories and fairy tales by Emilia Kiereś at the lexical and stylistic levels, as well as in the area of the Romantic philosophy of history. The aesthetics and meaning of the term "mystery" is associated with Romantic "feeling", magical idealism and intuition, while from a cultural, historical, and anthropological perspective it refers to folklore, the "secret knowledge" of the common folk and unexplained events of the past, often cruel and full of crimes. M. Maciejewski observes (1991: 929):

$[\mathrm{M}] \mathrm{ystery}$ becomes an indispensable sound box for the Romantic idea of infinity, for the philosophy of despair, for the past (memories) and the future (wishes), for fantasy motivated by folk culture, historicism, and the subconscious. ${ }^{10}$

\footnotetext{
${ }^{10}$ Mystery will play a special role in historical works. This is because these works will highlight the function of time, the passage of time, persistence, eternity, memories of sensational and unusual events from the past, and crimes that have remained unsolved over the centuries. According to Maciejewski (1991: 48), a place for these events will be created by "[...] castles and monasteries reconstructed with new imagination, which will be inhabited by heroes stigmatized by crime and modelled after Byron, who, like the voivode by Malczewski, in 'the shadows of the castle' hide the secret of their story, or dream fantastic dreams about the future" (cf. Goszczyński, 1839-1840: 58). A new, non-rhetorical creation of these characters - as postulated by W. Scott - involves taking away their voice ("There, his hidden thought is glowing by itself"). And here we face a psychological mystery, whose bearers are also Grażyna, Konrad Wallenrod, and Monk Robak from poems by Adam Mickiewicz.
} 
Here we should also mention the Jungian interpretation (Jung: 1993) of the phenomenology of spirit in fairy tales, where, among other things, the already archetypal forest (appearing, for instance, in the story Brat) becomes a big mystery. Despite the fact that the heroes of the story - the brothers Wir and Mir - have been brought up in a remote forest area, they only discover the activities of the Forest Spirit, a guardian of morality, during their unplanned and dangerous migration. The moral and ethical standards observed in the forest are plain and clear, but nature gets angry, and the Forest Spirit punishes the brothers for, among other things, the unjustified killing of a wild boar - the hunters were not hungry, thus violating the basic principle which grants the right to kill animals. On the other hand, the role of the Spirit - a guide, old man, and sage - is also fulfilled in the story by the forest Witch, who gives magical herbs to the wanderer, putting them into his shoe (e.g. sagebrush, which is to protect against fatigue, diseases, wild animals, and bad luck, as well as rosemary and rue, which protect against disaster). The image of the Witch is somewhat caricatured and stereotypical - the demonic woman has a scary appearance, is misshapen, has a clumsy, somewhat staggering gait, "her hump seemed to press her to the ground and her head, wrapped in rags, was wobbling on a long, wrinkled neck" (Kiereś 2011:51). However, she has an uncomplicated personality and friendly nature, and introduces herself with the following words (53): ${ }^{11}$

"I'm an ordinary witch", she paused, then laughed hoarsely. "I'm helping you because I can look into your heart. You're honest, brave, and faithful. You and your brother have to face a powerful force, pass a big test".

In the plots of both fairy tales (Brat and Łowy), the mystery is rooted in the past; the stories constantly return to the theme of an old, unresolved crime and as a result the books are infused with anxiety and dread. For example, in the story Łowy, whose plot is set in the settlement of Płużyny, a real location on the Polish Eastern Borderlands in 1809, there is a meeting of two real persons: Maryla Wereszczakówna and her brother Michał, a friend of Adam Mickiewicz. Near the Płużyny manor house, there is the famous Lake Świteź, and the local area is surrounded by mysterious, dense forests. This is the region where first the young Tadeusz, and then the shooter Jan, disappeared many years ago. The child heroes - Jan's brother Franek, Maryla, and Michał Wereszczak try to unravel the mystery of Jan's disappearance.

The imagination of the characters is also mysteriously stimulated by the play of light as well as by the vividness and poetic mood of the images presented in the story, abounding in poetic comparisons and epithets. The evocative style, visualisation, and polysensory narrative of these Romantic fairy tales present a constantly changing world. The non-stop "action" during the exploration undertaken by the heroes takes place in a reality that is filled with the colours and sounds of nature, while at other times it becomes grey, dark, and quiet, thus evoking sadness and fear, for example in the following example from Brat (Kiereś 2011: 37):

${ }^{11}$ See also "Fenomenologia Ducha w baśniach" in Archetypy $i$ symbole. Pisma wybrane by C.G. Jung (1993). A stereotypical image of a witch is also convincingly portrayed, among others, by B. Niesporek-Szamburska in Stereotyp "czarownicy" i jego modyfikowanie. Na przykładzie tekstów dla dzieci i wypowiedzi dziecięcych (2014). 
Larches burning gold already covered the ground with a luminous carpet of needles, gossamer threads were flying over the clearing and clinging to trees. The sun shone, winds blew, rain fell, and life in the woodcutter's cottages went on.

In another passage, the author writes (33):

Soon it got completely dark. Wir lay down by the fire. Quivering shadows were crawling on the surrounding trunks so the trees seemed to be dancing like ghosts. With the advent of night, Wir felt strangely uneasy and only now did the boy understand why the forest was constantly quiet. Nothing could be heard: no ordinary sounds of rustling, cracking, preying animals, or night birds. Wir moved closer to the fire and picked up his hunting knife to be ready, just in case. The longer he lay and listened, the more the silence seemed to absorb him. Whenever he closed his eyes, he felt as if he was falling into a black, soundless abyss. So he raised his eyelids and looked straight up at the sky. It was clearer than during the day. Elongated black clouds with green backlit edges were moving slowly across the sky. Here and there, single stars flickered coldly.

An additional asset of the story Łowy is the fact that the children's imagination also operates in the context of historical memory, which here has a clearly educational role. While the narrative of the story focuses on the search for the missing shooter, the author weaves into it information that one of the young heroes, Michat, is interested in heraldry and family histories, and collects old weapons, armour, and helmets that for many people are worthless scrap metal (the author uses the expression "metal junk" in the story (Kiereś, 2011: 109). But, in fact, “one mustn't throw away our own history into the barn. Who is going to remember it if we ourselves are not going to remember it?" (Kiereś 2012: 110).

With regard to the educational perspective, in both parables by Kiereś we can consider distinctive and clearly defined types of characters - models of a literary hero. It is worth remembering that Kiereś's stories are populated by both humans and fantastic creatures (e.g. forest spirits, rusalki, and bożatka, i.e. household goblins). Human characters are strongly typified, they have distinct characters (e.g. the brothers Mir and Wir, their mother Nawojka, and the domestic help Dobiechna, but also Franek, Maryla, and Michał) and they also make ideal personality models for use in school discussions of literature.

\section{Conclusion}

In both stories, the Romantic experience of existence, the mystery of nature, and the characters appear in the context of ethical values. Therefore, in addition to the convention of the Romantic fairy tale, both stories also take the genealogical form of a parable.

The ethical context in which the two stories are clearly rooted - especially considering the literary expectations of a young reader - enables the phenomenon of imagination to be observed and discussed also in terms of humanistic values, which are a very important aspect of Polish studies. The axiological perspective that is part of 
both narratives due to the internal dilemmas of the characters allows the moment of the heroes' transformations to be included in the interpretation of the stories. Paradoxically, the initial disappointment, rebellion against the family, its negation, and conflict in family relationships, coupled with the exhausting journey of the heroes, the existential experiences of a moral nature, and the deliberations of an ethical nature, provide an opportunity for open discussions, and for coming to an understanding, forgiveness, and reconciliation - the happy ending and return home. The journey of the heroes (from the story Brat) and the quest to find the truth about the missing young men (from the story Łowy), with the associated "rites of passage", are primarily a kind of search for one's own identity, a process of self-discovery and maturing to be able to talk openly, and find and name feelings and emotions, the meaning of friendship, and the value of love.

\section{References}

\section{Primary Sources}

Anon. 1992. Piękna Meluzyna. Cudowna historia o morskiej pannie i jej walecznym potomstwie. In Piękne historie o niezłomnym rycerzu Zygfrydzie, pannie wodnej Meluzynie, królewnie Magielonie i świętej Genowefie. Antologia jarmarcznego romansu rycerskiego, edited by Tadeusz Żabski \& Jolanta Ługowska, 41-75. Wrocław: Towarzystwo Przyjaciół Polonistyki Wrocławskiej.

Kiereś, Emilia. 2011. Brat [Brother]. Łódź: Akapit Press.

Kiereś, Emilia. 2012. Łowy [Hunting]. Łódź: Akapit Press.

\section{Secondary Sources}

Bachelard, Gaston. 1958/1961. La poétique de l'espace. $3^{\text {rd }}$ edition. Paris: Les Presses universitaires de France. <https://gastonbachelard.org/wp-content/uploads/2015/07/ BACHELARD-Gaston-La-poetique-de-l-espace.pdf $>$ (accessed 1 October 2016).

Bartoszewicz, Anotnina. 1991. Natura. In Stownik literatury polskiej XIX wieku, edited by Józef Bachórz \& Alina Kowalczykowa, 593-596. Wrocław: Ossolineum.

Brückner, Aleksander. 1918. Mitologia słowiańska. Kraków: Księgarnia G. Gebethnera \& sp., Gebethner \& Wolff.

Brückner, Aleksander. 1924. Mitologia polska. Warsaw: PWN.

Czabanowska-Wróbel, Anna. 1996. Baśń w literaturze Młodej Polski. Kraków: Towarzystwo Autorów i Wydawców Prac Naukowych „Universitas”.

Czabanowska-Wróbel, Anna. 2003. Dziecko. Symbol i zagadnienie antropologiczne w literaturze Młodej Polski. Kraków: Towarzystwo Autorów i Wydawców Prac Naukowych „Universitas”.

Czabanowska-Wróbel, Anna Misiak \& Iwona Misiak, eds. 2008. Żywioły wyobraźni poetyckiej XIX i XX wieku. Kraków: Wydawnictwo Uniwersytetu Jagiellońskiego.

Danek, Wincenty. 1975. Introduction. In Stara baśń: Powieść z IX wieku, Józef Ignacy Kraszewski. Reviewed and supplemented by S. Burko. Wrocław: Zakład Narodowy.

Dehnel, Piotr. 1992. Przyroda i historia: studium wczesnej filozofii F.W.J. Schellinga. Wrocław: Wydawnictwo Uniwersytetu Wrocławskiego.

Fijałkowski, Michał. 2014. Rusałki - słowiańskie ondyny. Acta Philologica (45): 219-227. $<$ yadda.icm.edu.pl/yadda/element/...f31e.../29_michal_fijalkowski.pdf $>$ (accessed 10 September 2015). 
Foucault, Michel. 1984. Des espaces autres. Architecture, Mouvement, Continuité (5 October): 46-49.

Foucault, Michel. 2005. Inne przestrzenie. Transl. Agnieszka Rejniak-Majewska. Teksty Drugie (6): 117-125.

Gieysztor, Aleksander. 1986. Mitologia Słowian. Warszawa: Wydawnictwa Artystyczne i Filmowe

Goszczyński, Seweryn. 1839-1840. Król zamczyska. Warszawa.

Jung, Carl Gustav. 1993. Fenomenologia Ducha w baśniach. In Archetypy i symbole. Pisma wybrane, Carl Gustav Jung. Transl. Jerzy Prokopiuk, 404-459. Warsaw: Czytelnik.

Koziełek, Gerard. 1967. Niemiecka baśń romantyczna. Wrocław: Wydawnictwo Uniwersytetu Wrocławskiego.

Labuda,Gerard. 2009. Pierwsze państwo słowiańskie. Państwo Samona. Wodzisław Śląski: Wydawnictwo Templum.

Lévi-Strauss, Claude. 1969. Myśl nieoswojona. Transl. Andrzej Zajączkowski. Warsaw: PWN.

Lévi-Strauss, Claude. 1970. Antropologia strukturalna. Transl. Krzysztof Pomian. Warsaw: Wydawnictwo KR.

Linkner, Tadeusz. 1998. Słowiańskie bogi i demony. Z rękopisu Bronisława Trentowskiego. Gdańsk: Wydawnictwo Marpress.

Maciejewski, Marian. 1991. Tajemnica. In Słownik literatury polskiej XIX wieku, edited by Józef Bachórz \& Alina Kowalczykowa, 928-931. Wrocław: Ossolineum.

Mochnacki, Maurycy. 1830. O literaturze polskiej w wieku dziewiętnastym. Warsaw: J. Węcki.

Natov, Roni. 2003. The Poetics of Childhood. London \& New York: Routledge.

Niesporek-Szamburska, Bernadeta. 2014. Stereotyp „,czarownicy” i je go modyfikowanie. Na przykładzie tekstów dla dzieci i wypowiedzi dziecięcych. Katowice: Wydawnictwo Uniwersytetu Śląskiego.

Ogrodowska, Barbara. 2001. Zwyczaje, obrzędy i tradycje w Polsce. Warsaw: Verbinum Wydawnictwo Księży Werbistów.

Pieciul-Karmińska, Elizy. 2014. 'Tajemnicze dziecko'- zapomniany skarb literatury światowej- A Word from the Translator. In Tajemnicze dziecko, E.T.A. Hoffmann, illustrated by A. Kucharska-Cybuch, 3-25. Poznań: Media Rodzina.

Podgórscy, Adam \& Barbara Podgórska. 2005. Wielka księga demonów polskich. Leksykon $i$ antologia demonologii ludowej. Katowice: Wydawnictwo KOS.

Sainsbury, Lisa. 2013. Ethics in British Children's Literature: Unexamined Life. London \& New York: Bloomsbury.

Schiller, Fryderyk. 1953. Opoezji naiwnej i sentymentalnej (Übernaive und sentimentalische Dichtung), [1795-1796]. Marbach.

Strzelczyk, Jerzy. 1998. Mity, podania $i$ wierzenia dawnych Słowian. Poznań: Dom Wydawniczy Rebis.

Szyjewski, Andrzej. 2003. Religia Słowian. Kraków: Wydawnictwo WAM.

Urbańczyk, Stanisław. 1991. Dawni Słowianie: wiara i kult. Wrocław: Ossolineum, Polska Akademia Nauk, Komitet Słowianoznawstwa.

Waksmund, Ryszard. 2000. Od literatury dla dzieci do literatury dziecięcej: tematy gatunki - konteksty. Wrocław:Wydawnictwo Uniwersytetu Wrocławskiego.

Witkowska, Alina \& Ryszard Przybylski. 2009. Romantyzm. Warsaw: Wydawnictwo Naukowe PWN.

Zgorzelski, Czesław. 1948. O pierwszych balladach Mickiewicza. Pamiętnik Literacki 38: $72-149$. 
Zgorzelski, Czesław. 1962. Introduction”. In Ballada polska, edited by Czesław Zgorzelski, v-xxix. Wrocław [etc.]: Zakład Narodowy im. Ossolińskich.

Zgorzelski, Czesław. 1978. Od Oświecenia ku Romantyzmowi i współczesności. Kraków: Wydaw.

\section{Dorota Michułka}

Sveučilište u Wroclawu, Poljska

Universität Wrocław, Polen

\section{Prelaženje granica mašte}

Romantičarsko iskustvo postojanja, prirode i zagonetnosti likova u paraboličnim bajkama Emilije Kiereś Brat i Lowy

Etički kontekst u koji su priče Brat i Łowy [Lov] Emilije Kiereś jasno ukorijenjene (naročito uzmemo li u obzir čitateljska očekivanja mlađe publike) omogućava razmatranje fenomena mašte i raspravu o njemu i u odnosu na humanističke vrijednosti koje predstavljaju važan aspekt polonistike. Snaga mašte protagonista i prelaženje njezinih granica u Kiereśinu stvaralaštvu predstavljaju neku vrstu etičkoga imperativa koji junake potiče na djelovanje. U objema pričama Emilije Kiereś - koje su duboko ukorijenjene u poetici bajke, fantastike i usmene priče - romantičarsko iskustvo postojanja, tajne prirode i likovi javljaju se u kontekstu etičkih vrijednosti. Stoga, osim konvencija romantičarske bajke, obje priče također preuzimaju genološki oblik parabole.

Ključne riječi: mašta, etičke vrijednosti, romantičarska bajka, parabola, folklor, priroda, zagonetnost

\section{Überschreitung der Grenzen der Phantasie \\ Romantische Erfahrung der Existenz, der Natur und der rätselhaften Gestalten in den Parabelmärchen Brat und Lowy von Emilia Kiereś}

Der ethische Kontext, worin die Geschichten Brat und Łowy von Emilia Kiereś eingebettet sind, ermöglicht - beachtet man insbesondere die Leseerwartungen des jüngeren Publikums - die Hinterfragung der Phantasie auch in Bezug auf die humanistischen Werte, diesen derart wichtigen Bestandteil der Polonistik. Die Einbildungskraft der Protagonisten und das Überschreiten der Grenzen der Phantasie stellen eine Art ethischen Imperativs dar, der die Helden zum Handeln bewegt. In beiden Geschichten, die tief in der Poetik des Märchens, der Fantastik und der mündlichen Überlieferungen verwurzelt sind, kommt die romantische Erfahrung der Existenz, der Natur und der Gestalten im Kontext von ethischen Werten zum Vorschein. Aus diesem Grund beruhen beide Texte nicht nur auf den Konventionen der romantischen Märchenproduktion, sondern nehmen darüber hinaus die genealogische Form einer Parabel an.

Schlüsselwörter: ethische Werte, Folklore, Natur, Parabel, Phantasie, Rätselhaftigkeit, romantisches Märchen 